\title{
Education - An Inportant Factor in Employment
}

\author{
Dr. Doreta Kuçi (Tartari) \\ Departament of Sociology. Universiteti "Aleksandër Moisiu" Durrës, Lagja 1 \\ Rruga Taulantia Currila, Albania; doretatartari@yahoo.it
}

\section{Doi:10.5901/jesr.2016.v6n1p22}

\begin{abstract}
When we talk about education, we always associate it with educational institutions because without education we will not have a healthy society, therefore, we say that these two components are connected between them. Education is relevant enough with the process of socialization as one of the basic processes of society. Given that education is a process of special importance in the formation of the human personality is responsible for national problems trace back to a single word, the word Education. The most important institution of education created by the company is schools. Then Employmentis an important factor of education as a well-educated person is able to be employed by the respective school. The article will focus mainly on this phenomenon which besides the definition of education and employment will talk about these two phenomena today. The work will also Highlight the issues that are related to education and employment. The work will be mainly based on a review of previous studies in this field and it will also bring different innovation of nowadays.
\end{abstract}

Keywords: Education, Educational institution, Employment, Phenomena, Socialization

\section{Education}

Education is the investment that our current generation did for the future. "- Mitt Romney

\subsection{What advantages bring education?}

Having an education is to give a greater chance to find a job that can pay more than the minimum wage in your country. A formal education, along with the time spent in learning on behalf of the student can produce qualifications and credentials that will help to get a management position of a job.

Education also improves you as a human being. It helps you achieve the full development of your potential. Learning (ie learning) is the most powerful device in the world. The more you know, the better you can live life to the world.

\subsection{Education is the best investment you can make}

In the same way that saves money to buy something special, you need to plan and invest money and time to reach your dream job and achieve your goals. In uncertain economic times, you probably can hesitate spending money to advance your career. But accurate investment of money and time can have a reward for you.

"As we enter the 21st century, it is very clear that education is, indeed, the greatest investment we can do, as for information, economy relies on an educated workforce, knowledgeable, and capable. The more that we educate our students, the better it will prosper in our economy. "- Bill Gates

Education is a very significant phenomenon of all time and especially today in modern times for the very reason that society cannot live if there is not a sufficient homogeneity among its members; education strengthens such homogeneity.

According to Parsons, the function of education is to brand his role in the transmission of values and the preservation of the social role.

Durkheim also believed that education gives children the opportunity to internalize social rules; it plays an important role in the socialization of children, preparing them for their role in society.

It is one of the means by which dominant culture is transmitted. 


\subsection{Education}

It has long been recognized that education is a fundamental right, with long-term consequences for human development and progress. Education is also essential for the empowerment of women and to close the gap between women and men in the use of social-economic opportunities.

On an annual basis, the Albanian education sector produces a variety of statistics on education and all key indicators are divided by sex and age.

Existing data show significant differences between girls and boys in various aspects related to education. Differences in education are evident in compulsory preschool and secondary school; a much higher percentage of boys attend public preschools, while girls' enrollment has declined, especially in urban Tirana. After compulsory education, boys are $10 \%$ more likely to continue their education in high school. However, at the end of high school, a higher percentage of girls receive a diploma, compared to boys.

Significant gender differences are observed also in higher and tertiary education, while men make up the majority of all students enrolled in vocational schools, about two-thirds of students in a day universities in Albania are women. In both types of education, there is a visible division on the basis of sex courses and disciplines according to traditional gender roles. Access to education is not yet secured for minority groups: School dropout rate of children with disabilities is approximately ten times greater than the overall rate of school dropout; while the rate of participation in schools of Roma girls is significantly lower than that of Roma boys. Despite the high percentage of female staff in the education system, the distribution of women in decision making positions follows the traditional pyramid model: the percentage of women directors does not exceed 30 per cent in any of the levels of education.

\section{Employment}

Employment is the activity performed in exchange for a regular wage or salary.

Employed persons are all persons 15 years and over who during the reference period have worked against a salary or profit, or during the reference period were not working but had a job in which they were temporarily absent. This includes unpaid family workers (according to international definitions of the International Labour Organization).

Employment is an area which cannot be seen isolated itselfby analysingself-employment laws or strategies. This area is influenced significantly by a number of factors which can mention child care,flexible schedule, as well as general permit policies and in particular those of maternity leave (Johnson \&Provan, 1995) because they are indicators of the needs of family and to be considered thoroughly. So employment practices are directly related to women's participation in the labor market.

The official employment rate is generally higher for men than for women. During the period of 2007-2013 (according to LFS), the employment rate for women dropped from $49.3 \%$ to $38.4 \%$.At the same time, employment of men has remained unchanged, with a decline from $63.6 \%$ to $51 \%$. The recent dynamics of employment has resulted in a narrowing of the overall employment gap between women and men by almost 12.6\% percentage points in 2013.

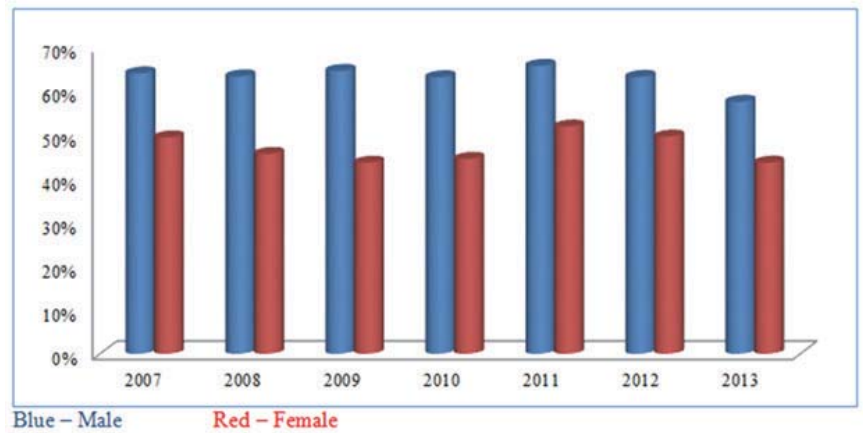

Picture 1: Employment rates by gender for 2007-2013

Source: INSTAT , Labour Force Surveys 2007-2013 


\section{Human Poverty Indices}

Human poverty indices use additional subcomponents in developing and transition countries, covering some vital aspects of human development, which are present in these countries. During the period of 2005-2008 the Human Poverty Index (HPI) 1, which includes ingredient elements such as: connection with drinking water sources, the weight of children under five years and the probability of reaching age 40 , was mainly upgraded due to the improved stable connectivity with water sources in rural areas.

The second indicator of poverty, HPI 2 presents the changes of the percentage of population living below the poverty line, differences in unemployment rates and includes the percentage of illiteracy and the probability of failure reaching 60 years of age. During the period of 2005-2008, improved HPI 2 is mainly due to the decrease in the number of people living below the poverty line. However, this improvement has been observed in more developed parts of the country, while in the mountainous areas there has been no change (UNDP Report on Human Development in Albania, 2010).

During the period of 2007-2013 the overall labor force participation rate (ie, the proportion between the economically active population aged 15 to 64 years and the working age population) decreased for both men and women. However, while the participation of men in the labor market remained almost stable, the participation of women in the labor market has fallen more drastically than the participation of men and the responsive gap gender expanded from $18.2 \%$ in 2007 to $21.5 \%$ in 2013, highlighting lesser access of women in the labor market, in relation to that of men. Withdrawal of women from the labor market may be an indicator of hopelessness on their part to find a suitable job due to the economic crisis. In this case, the growing attractiveness of women would be only temporary, and this trend can be turned back once economic growth resumes.

On the other hand, the phenomenon could be an obvious reaction to the kinds of jobs that may exist for women in general, showing a domestic structural problem of the labor market, certain groups of women may be discouraged from participating in the labor market due to the relative large number of less skilled jobs in agriculture and production and limited diversification of production and employment opportunities in other sectors. Notable gender gap and increasing participation in the workforce requires careful monitoring and the development of appropriate labour measures policies, in order to give women equal opportunities in the economy.

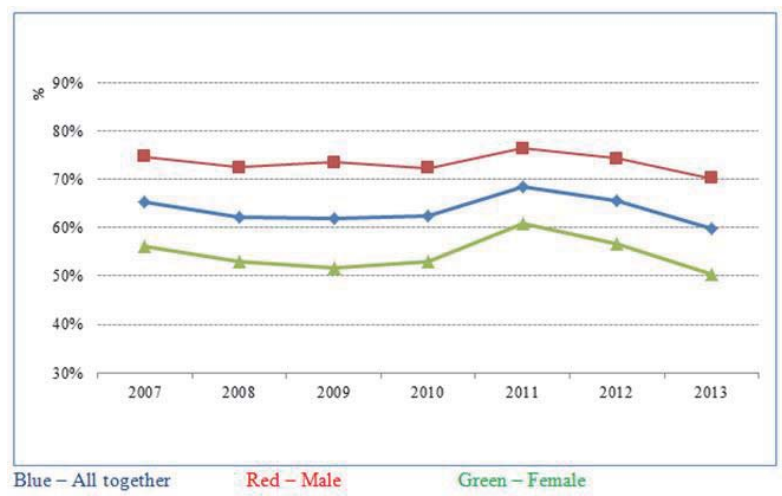

Figure 2: The participation rate in the labor force, by sex 2007-2013

Source: INSTAT , Labour Force Survey , 2007-2013

\section{The Inactivity Rate}

Refers to the percentage of people who in principle could be ready to enter the labor market, but who are not registered as employed or unemployed. These include persons attending educational institutions, deal with housework, retired or cannot enter the labour market due to their limited abilities or disabilities.

There is a significant gender difference in the activity rates of women and men; and this difference, divided by gender, is greater for people without education. According to the Labour Force Survey (LFS) 2013, the inactivity rate was 
$29.8 \%$ for men and almost two times greater for women, ie $49.6 \%$. This reflects the recent tightening of the labor market in terms of opportunities for women to find work and also their withdrawal from the labor market. Such a reaction is encouraged by traditional gender stereotypes of men as bread winners; and women primarily as caregivers.

Another possible factor, which is suggested to have influenced the degree of passivity of women, is migration. Although there is a positive correlation between internal migration and finding work by women, the opposite is proven to the international migration of men; the entry of remittances may serve as a factor that discourages women to seek paid work (Plaku, Agolli and Danaj (2011) based on LSMS -LSMS 2008).

Many people of working age in Albania, mainly in urban areas as well as in rural areas, have withdrawn from the labor market because of the remittances which are higher than income from formal employment. This phenomenon is more obvious in women, men and boys of whom are working abroad (Kodra, F. The impact of the wage crisis in Eastern Europe. ILO 2011). This effect was seen to be more visible to married women than to single women, showing their involvement in the affairs of unpaid care at home (Plaku, Agolli and Danaj (2011) based on Measurement Survey of the Living (LSMS) 2008).

However, the economic crisis in host countries has led to a reduced remittances and, in fact, an increase in those who return (Azzarri\&Carletto (2009) Modeling the Dynamics of Migration in Albania. A note on studies Bank policies World World Bank Policy Research Paper 4945)

The latter raises doubts about whether the dependence on remittances, could be still considered a strategy for maintaining income and economic welfare of women (and their children). A comparison of age groups over the years could be interesting to further investigate gender dynamics and trends over time.

The trend of withdrawal from the labour market andthe focus on the obligations of marriage and family, care for the young and the elderly is a phenomenon "deeply" feminine and a mechanism that, apparently, helps to cope with the current critical labour market situation. However, the withdrawal of women from the labor market is associated with social isolation, closure in their role as trustee reproductive and economic addiction. In addition, as long as women remain outside the labor market, the more are they in danger of losing their human capital and therefore their economic position and labour market rewards. The associated economic losses in terms of skills and resources for the further development of the country are important. In addition, this particular reaction negatively affects utilization of women's rights and those belonging, as well as their overall position in society.

\section{Employment by Education}

Chart : "Percentage of employed women / girls and boys / men by education track" shows that most girls / women and boys / men employed have only finished compulsory education, showing how the labor market is composed of a work force with low qualifications. According to the labor force survey in 2013, $60 \%$ of employed women / girls have a job that requires a low-skilled, and where this figure is about $7 \%$ higher than the proportion of men. Moreover, such employment is based on employment of unqualified and often characterized by informality.

In students is evident a higher percentage of girls employed. However, the end of any other education in percentage turns out to be lower for girls than for boys, in order to find a job. The gender gap is particularly evident in vocational education, which clearly shows the existence of barriers for young girls graduated in vocational education, to find a job. Although the percentage of boys who finish the general high school is lower, this education seems to offer girls a lesser chance to find a job, compared to boys: $17.5 \%$ of girls in this category are employed, compared with $22.4 \%$ of boys.

Taken together, the women / girls appear to have less opportunity and more inequality in employment, compared with men of the same educational level. This phenomenon is more evident in vocational education, making visible the fact that this kind of education still does not reward enough girls in the labour market. Observed such a phenomenon : the high percentage of female employment is found in an unskilled employment or employment that requires a high qualification. These findings go on line that shows that on one hand we have a high percentage of theiragriculture and textiles, as well as their employment in the finance and public sector. 
Chart: Percentage of employes by level of education and gender

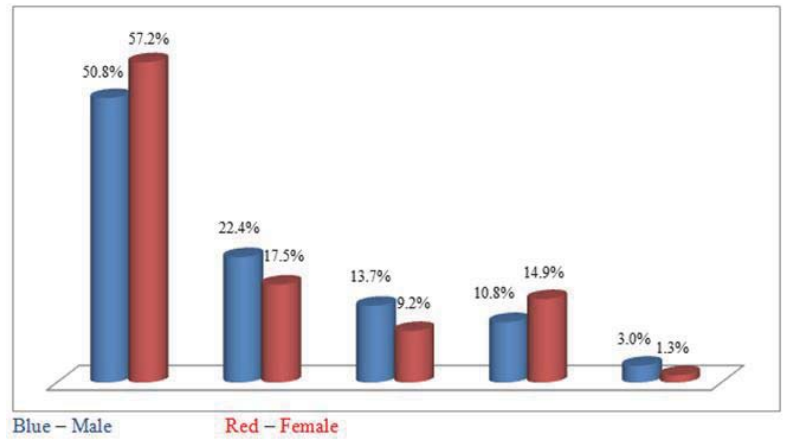

Source: INSTAT , Labour Force Survey 2013

\section{References}

Durkheim, E. (1973). Moral education: A studyin the theory and application of the sociology, Free Press. New York.

Floud, J. And Hasley, A.H. (1958) The Sociology of Education, Current Sociology 7, no. 3.

Parsons, T. (1959). The school class as a social system: Some of its functions in American society. Harvard Education Review 29: 291313

Taylor, G. (1993a). "Socialism \& Education: Saint-Simon", General Educator: Journol of Natfe General Education Section, Issue 24, September-October, $15-18$.

INSTAT, (2013), Shqipëri: Tendencat e Varfërisë (2002-2012), Tiranë

INSTAT, 2012-2013. Tregu i punës, Tiranë.

Petersen, A.\&R. Willig. (2004). "Work and Recognition: Reviewing New Forms of Pathological Developments". Acta Sociologica 47 (4): 338-50.

Romero, D., Chavkin, W., Wise, P.H., Smith, L.A.,\&Wood, P.R.2002. "Welfare to work? Impact of maternal health on employment," American Journal of Public Health, no.92, 1462-1468. 